\title{
HUBUNGAN LAMANYA PEMBERIAN SUSU FORMULA DENGAN TINGKAT KEPARAHAN KARIES GIGI PADA ANAK USIA 4-6 TAHUN DI TK PANCAMARGA KECAMATAN TANETE RIATTANG BARAT KABUPATEN BONE
}

\author{
Johnny Angki, Sainuddin
}

\begin{abstract}
ABSTRAK
Kesehatan gigi dan mulut merupakan bagian dari kesehatan tubuh yang tidak dapat dipisahkan satu dengan yang lainnya, terutama pada anak usia prasekolah yang sedang dalam masa penting dalam perkembangan fisik dan psikologisnya. Masalah gigi berlubang dialami oleh $85 \%$ anak dibawah umur 5 tahun di Indonesia salah satu penyebabnya adalah kebiasaan minum susu formula sebagai pengganti ASL Selain susu formula, terjadinya karies juga dapat ditimbulkan akibat kebiasaan mengkonsumsi makanan/minuman yang manis, misalnya coklat, permen, clan jus. Dengan rentang waktu mengkonsumsi makanan tersebut yang relatif lama sehingga menimbulkan bercak putih atau kecoklatan yang kemudian berkembang menjadi lubang gigi. Tujuan penelitian ini adalah untuk mengetahui hubungan lamanya pemberian susu formula dengan tingkat keparahan karies gigi pada anak usia 4-6 tahun di TK Pancamarga Kecamatan Tanete Riattang Kabupaten Bone. Jenis penelitian ini adalah penelitian observasional analitik dengan rancangan cross sectional. Teknik analisis data kuantitatif dilakukan dengan pengolahan data dari kuesioner dengan menggunakan perhitungan manual clan disajikan dalam bentuk tabel sederhana. Pengambilan sampelpenelitian dilakukan dengan tehnik Quota sampling yang terdiri dari 50 orang anak TK Pancamarga. Tingkat keparahan karies diukur dengan pemeriksaan Caries Severity Index (CSI). Analisis data menggunakan Uji Statistik Hubungan Perorangan. Hasil penelitian menunjukkan bahwa 24 sampel $(48,0 \%)$ yang mengkonsumsi susu formula clan terjadi karies, sedangkan 11 sampel $(22,0 \%)$ yang tidak mengkonsumsi susu formula clan tetap terjadi karies. Adapun responden yang memberikan susu formula dan terjadi karies berjumlah 8 sampel $(16,0 \%)$, sedangkan responden yang tidak terjadi karies sebanyak 2 sampel (14,0\%). Hasil skor rata-rata tingkat keparahan karies pada anak yang minum susu formula adalah 0,16 dan yang lama minum susu formula adalah 0,33. Terdapat hubungan antara lamanya pemberian susu formula dengan tingkat keparahan karies pada anak usia 4-6 tahun di TK Pancamarga Kecamatan Tanete Riattang Barat Kabupaten Bone karena $(p<0,05)$.
\end{abstract}

Kata Kunci : gigi, karies, susu formula

\section{PENDAHULUAN}

Masa usia prasekolah adalah anakanak yang berusia 1-6 tahun (Soedjiningsinh, 1995). Dimana pada usia tersebut anak mengalami proses tumbuh kembang dengan baik dari fisik, mental dan sosial. Proses tumbuh kembang sangat terkait dengan faktor kesehatan dengan kata lain hanya pada anak yang sehat dapat diharapkan terjadi proses tumbuh kembang yang optimal (Kumia, 2008).

Karies merupakan suatu penyakit jaringan keras gigi, yaitu email, dentin dan sementum, yang disebabkan oleh aktivitas suatu jasad renik dalam suatu karbohidrat yang dapat diragikan (Kidd, Edwina A.M, 2013). Kerusakan gigi dapat terjadi karena karies gigi, atrisi (aus karena gesekan gigi ke gigi), abrasi (penyikatan gigi yang salah, dengan pasta gigi yang abrasif), erosi (dari asam), fraktur, dan rusaknya tambalan (Scheid, Rickne.C, 2002).

Karies gigi menjadi masalah kesehatan yang penting karena kelainan pada gigi ini dapat menyerang siapa saja sumber fokol infeksi dalam mulut sehingga menyebabkan keluhan rasa sakit (Kusumawati, 2010).

Data dari Who pada tahun 2003 menggambarkan bahwa angka kejadian karies pada anak sekitar 60-90\% kasar. Anak usia 4-5 tahun yang tinggal didaerah pedesaan mengalami 95,5\% kejadian karies gigi dengan nilai def-t 7,98 dan anak yang tinggal didaerah perkotaan mengalami 90,5\% kasus karies gigi dengan nilai def-t 7,92 (Pratiwi Said, 2018).

Menurut WHO (World Health 
Organization) pada tahun 2012 masih banyak anak yang mengalami karies didunia dengan presentase $60-90 \%$ (Jenatu, 2014) Menurut Riskesdas tahun 2013 pravalensi nasional masalah gigi dan mulut diatas angka nasional salah satunya Provinsi Jawa Timur 28,6\% berdasarkan required treatment index (RTI) di Provinsi Jawa Timur menunjukkan bahwa pravalensi anak usia 1-2 tahun yang menderita karies $66,7 \%$ dan yang bebas karies $33,33 \%$ (Martapura, 2012 dalam Sumini 2014).

Menurut Survey Demografi Kesehatan Indonesia, Penggunaan ASI tahun 1997 dan 2002 menurun yaitu dari $42,4 \%$ menjadi $39,5 \%$. Sementara itu, penggunaan susu formula meningkat lebih dari 3 kali lipat dari 10,8\%menjadi 32,5\% (Wiguna, 2007). Data statistik menunjukkan bahwa wanita bekerja saat ini meningkat terutama yang hidup di kotakota besar, pergeseran paradigma itu dipicu oleh tingginya tingkat kebutuhan hidup dan meningkatnya pemahaman kaum wanita tentang aktualisasi diri.

Susu formula adalah susu yang diproduksi oleh industri untuk keperluan asupan gizi yang sesuai dan bisa diterima sistem tubuh anak. Susu formula yang baik tidak menimbulkan gangguan saluran cerna seperti diare, muntah atau kesulitan buang air besar dan meningkatkan kejadian karies gigi susu pada anak. Hal ini sesuai dengan pendapat Endang (2014) bahwa kesehatan gizi dipengaruhi oleh gizi makanan, macam-macam makanan, kebersihan gizi dan kepekaan air liur. Salah satu masalah kesehatan gigi dan mulut yang sering kita jumpai di masyarakat saat ini adalah karies gigi atau sering disebut gigi berlubang. Lubang ini muncul diakibatkan oleh kerusakan yang terjadi pada struktur gigi, baik luar maupun pada bagian dalam. Faktor utama penyebab karies gigi antara lain makanan/minuman yang manis dan bisa menyebabkan terjadinya fermentasi karbohidrat misalnya cokelat, permen, susu formula dan jus dan kurang memperhatikan kesehatan gigi dan mulut atau dengan kata lain kurang mengsosok gigi.

Peneliti melakukan penelitian di TK Panca Marga Kecamatan Tanete Riattang Barat Kabupaten Bone yang merupakan wilayah kerja puskesmas Watampone, Jarak tempat TK ini dari Puskesmas kira-kira 2 kilometer, karena pada saat peneliti melakukan kunjungan ke sekolah ini sebagian besar anak anak membawa dot yang berisi susu formula ke sekolah, dan sebagian besar orang tua siswa di TK ini mayoritas pekerja seperti pegawai, berkebun, berdagang, dan peternak, sehingga para orangtua setiap hari sibuk dengan pekerjaannya, makanya jalan pintas yang dilakukan dengan cara memberikan susu Formula kepada anak anaknya dan para orang tua juga belum tahu pasti dampak atau kerugian dari pemberian susu formula yang terlalu lama yang dapat mengakibatkan terjadinya karies.

Susu formula berasal dari susu sapi, seperti yang kita ketahui bahwa pada umumnya susu formula yang beredar di pasaran adalah susu sapi. Salah satu gejala yang ditimbulkan jika anak alergi terhadap jenis susu ini yakni apabila mengalami gejala seperti diare. Hal ini di karenakan antara usia 4 sampai 6 bulan persediaan zat besi pada tubuh bayi mulai berkurang sehingga perlu mendapatkan tambahan asupan dari luar. (Nirwana, A.B. 2014). Yang membedakan ASI dan susu formula adalah terletak pada zat imunnya. Dalam ASI terdapat zat imun yang terletak pada immunoglobulin, sektori dan laktoferin zat imun tersebut bersih dan bebas kontaminasi immunoglobulin yang berfungsi sebagai pencegah terjangkitnya penyakit pada bayi. Zat sekretori ini beguna untuk melumpuhkan bakteri pathogen e-coli dan berbagai virus saluran pencernaan. Sedangkan zat laktoferin berguna sebagai zat kekebalan yang berfungsi mengikat zat besi di saluran 
pencernaan.

Kandungan ASI yang banyak tersebut sangat bermanfaat bagi kondisi bayi yang membutuhkan gizi yang tinggi sementara kondisi tubuh yang masih lemah dan sistem pencernaannya belum sempurna. Kandungan nutrisi yang sangat banyak tersebut sangat mudah dicerna dan diserap oleh pencernaan bayi. Hal ini dikarenakan pada ASI memiliki perbandingan whei dan casein yang sesuai untuk bayi. Seperti yang teiah di bahas di atas, ASI mempunyai sejuta manfaat dan susu formula pun ingin menyerupai segala kandungan yang ada dalam ASI. Meskipun susu formula tersebut dimodifikasi sedemikian rupa sesuai kandungan ASI tentu tidak akan sama dengan ASI. (Nirwana A.B, 2014).

Rampan karies merupakan Proses karies yang tidak dapat dikontrol karena jalannya sangat cepat, menyebar secara luas dan mengenai pulpa. Karies ini mengenai beberapa gigi, gigi yang biasanya bebas karies adalah gigi anterior bawah dan yang banyak ditemukan pada gigi sulung anak karena mengkonsumsi makanan dan minuman kariogenik atau pada anak balita yang sering mengkonsumsi makanan kariogenik diantara makanan utamanya, Rampan karies merupakan lesi akut yang meliputi sebagian atau seluruh gigi yang telah erupsi, mrenghancurkan jaringan mahkota gigi dengan cepat termasuk permukaan yang biasanya tahan terhadap karies, serta mengakibatkan terkenanya jaringan pulpa. (Mariati, N.W. 2015)

Rampan karies yang spesifik adalah baby bottle caries. Terdapat pada anak - anak yang berhubungan dengan riwayat masa bayi yang tertidur dengan menggunakan susu botol yang masih di dalam rongga mulut yang berisi minuman yang mengandung gula, pemberian air susu ibu dengan periode yang lama atau memakai dot kosong yang dicelupkan dalam madu, sirup atau gula. Frekuensi makanan karbohidrat yang tinggi pada anak dengan kebiasaan tidur minum susu botol merupakan penyebab utama dari penularan bakteri kariogenik (Mariati, N.W. 2015).

Dalam pengendalian karies, perawatan karies rampan harus dilakukan secara sistematis dan komphrensif serta sesuai dengan prinsip pencegahan dan perawatan secara menyeluruh. Hal selanjutnya yang dilakukan dalam perawatan ialah mengurangi aktifitas bakteri untuk menghentikan karies dan mencegah penjalaran yang cepat kearah pulpa untuk mengurangi perkembang biakan bakteri serta adanya bau mulut juga perlu dilakukan oral profilaksis dengan cara menyikat gigi secara benar dan teratur.

Maka dari itu peneliti tertarik melakukan pemeriksaan pada TK Panca Marga Kecamatan Tanete Riattang Barat Kabupaten Bone dan mencari hubungan lamanya pemberian susu formula terhadap tingkat keparahan karies gigi pada anak usia 4-6 tahun di TK Panca Marga Kecamatan Tanete Riattang Barat Kabupaten Bone. Dan peneliti juga akan memberikan penyuluhan kepada orang tua siswa/siswi mengenai dampak/kerugian yang diakibatkan penggunaan Susu Formula yang terlalu lama.

\section{METODE PENELITIAN}

Jenis penelitian ini adalah penelitian adalah penelitian observasional. Penelitian ini dilakukan di TK Panca Marga Kecamatan Tanete Riattang Barat Kabupaten Bone. Waktu penelitian ini dilakukan Pada Bulan Januari 2020. Populasi dalam penelitian ini adalah seluruh siswa dan siswi TK Panca Marga Kecamatan Tanete Riattang Barat Kabupaten Bone. Siswa dan siswi TK Panca Marga Kecamatan Tanete Riattang Barat Kabupaten Bone memenuhi Kriteria inklusi sebanyak 50 orang. Tehnik Pengumpulan Data dengan mengggunakan Indeks CSI (Caries Saverity Index) yang diintroduksi oleh WHO kemudian dimodifikasi oleh Shimono (1995), untuk mengukur tingkat keparahan karies gigi. Kategori kriteria penilaian 
untuk mengetahui parah atau tidaknya karies tersebut menggunakan kategori penilaian menurut WHO. Kuisioner yang berisi pertanyaan tentang lama pemberian susu formula pada anak. Panduan penilaian dan pemberian skoring kuisioner dengan menggunakan skala likert. Untuk kriteria penilaian adalah sebagai berikut, untuk pernyataan positif, Ya bernilai 3, Kadangkadang bernilai 2, dan Tidak bernilai 1. Namun, untuk pernyataan negatif, Ya bernilai 1, Kadangkadang bernilai 2, Tidak bernilai 3 Kriteria objektif untuk kebiasaan baik dan buruk Baik jika responden mempunyai skor lebih dari $66,7 \%$ Buruk jika responden mempunyai skor kurang dari $66.7 \%$.

Data hasil penelitian yang diperoleh dianalisis dengan menggunakan tehnik statistic spearman Rank Colleration yang pada umumnya digunakan untuk menganalisis data pada penelitian yang berskala ordinal. Tehnik uji statistik Spearman Rank Colleration ini digunakan untuk mengetahui hubungan lamanya pemberian susu formula dengan tingkat keparahan karies gigi pada anak usia 46 tahun di TK Panca Marga Kecamatan Tanete
Riattang Barat Kabupaten Bone.

\section{HASIL PENELITIAN}

Penelitian ini merupakan penelitian observasional dan pengambilan data pada sampel penelitian yang dilakukan dengan dua metode pengukuran yaitu pemberian Kuesioner bagi orang tua murid sampel tersebut. Dan secara klinis, sampel diperiksa dengan menggunakan indeks keparahan karies (CSI). Melalui jawaban kuesioner tersebut dapat diperoleh data-data dasar mengenai identitas sampel, riwayat pemberian air susu ibu (ASI) maupun pemberian susu formula, riwayat sampel mengkonsumsi makanan manis, perilaku menjaga kesehatan gigi anak dan cara pemberian susu formula, serta kurun waktu awal mula penggunaan sikat gigi pada anak.

Adapun pemeriksaan secara klinis dilakukan secara langsung dengan menggunakan acuan CSI. Seluruh hasil penelitian dikumpulkan selanjutnya melakukan analisis data dari hasil pemeriksaan klinis tersebut. Hasil analisis data ditampilkan dalam tabel distribusi sebagai berikut :

Tabel 1 Distribusi Karakteristik Sampel Penelitian Berdasarkan Jenis Kelamin

\begin{tabular}{|c|c|c|}
\hline Jenis Kelamin & Frekuensi (n) & Persen (\%) \\
\hline Laki-Laki & 19 & 38 \\
Perempuan & 31 & 62 \\
\hline Total & $\mathbf{5 0}$ & $\mathbf{1 0 0}$ \\
\hline
\end{tabular}

Tabel 1 menunjukkan distribusi karakteristik sampel penelitian yang memiliki jumlah sebanyak 50 (Lima Puluh) orang dengan jumlah laki-Laki sebanyak 19 (Sembilan Belas) orang dengan persentase 38\%. Sedangkan Sampel Perempuan lebih banyak yaitu sebanyak 31 (Tiga Puluh Satu) orang dengan persentase $62 \%$. Rata-rata usia pada pada penelitian ini adalah umur 5-6 Tahun.

Tabel 2 Distribusi Karakteristik Sampel Penelitian Berdasarkan Pemberian Susu Formula

\begin{tabular}{|c|c|c|}
\hline \multicolumn{1}{|c|}{ Minum Susu Formula } & Frekuensi (n) & Persen (\%) \\
\hline Ya & 32 & 64 \\
Tidak & 18 & 36 \\
\hline Total & $\mathbf{5 0}$ & $\mathbf{1 0 0}$ \\
\hline
\end{tabular}


Sampel penelitian lebih banyak minum susu formula dari pada yang tidak minum susu formula yaitu 32 (Tiga Puluh Dua) orang yang minum susu formula dengan persentase $64 \%$, dan 18 (Delapan Belas Orang) orang yang tidak minum susu formula dengan persentase $36 \%$ (tabel 2). Sampel yang mengalami karies gigi mencapai 41 (Empat Puluh Satu) orang (82\%), sedangkan yang tidak mengalami karies gigi hanya mencapai 9 (Sembilan) orang (18\%) ketika dilakukan pemeriksaan secara klinis (tabel 3).

Tabel 3 Distribusi Karakteristik Sampel Penelitian Berdasarkan Kejadian Karies

\begin{tabular}{|l|c|c|}
\hline \multicolumn{1}{|c|}{ Kejadian Karies } & Frekuensi (n) & Persen (\%) \\
\hline Karies & 41 & 82 \\
Tidak karies & 9 & 18 \\
\hline Total & $\mathbf{5 0}$ & $\mathbf{1 0 0}$ \\
\hline
\end{tabular}

Tabel 4. Lama Pemberian Susu Formula dengan Jumlah Gigi yang Terkena Karies

\begin{tabular}{|c|c|c|}
\hline Lama Pemberian (Tahun) & $\begin{array}{c}\text { Jumlah Gigi yang Terkena } \\
\text { Karies }\end{array}$ & Persentase (\%) \\
\hline $0-1$ & $3-5$ & $9,4 \%$ \\
\hline $0-2$ & $5-9$ & $11,2 \%$ \\
\hline $0-3$ & $9-15$ & $20,6 \%$ \\
\hline $0-4$ & $15-18$ & $23,3 \%$ \\
\hline $0-5$ & $18-20$ & $35,5 \%$ \\
\hline \multicolumn{2}{|c|}{ Total } & $100 \%$ \\
\hline
\end{tabular}

Tabel 4 menunjukkan lamanya pemberian susu dengan jumlah gigi yang terkena karies. Terlihat bahwa responden yang memberikan susu formula pada anak usia 0-1 tahun dapat terjadi rampan karies 3-5 gigi anak $(9,4 \%)$. Sedangkan responden yang memberikan susu formula pada anak usia 0-2 tahun gigi yang terkena karies 5-9 gigi anak (11,2\%). Ibu yang memberikan susu formula 0-3 tahun lebih banyak gigi yang terkena karies yaitu 9-15 gigi (20,6\%), sedangkan responden yang memberikan susu formula pada anak usia 0-4 tahun lebih banyak lagi gigi yang terkena karies yaitu 15-18 gigi $(23,3 \%)$. Selain itu karies meningkat, responden yang memberikan susu formula pada anak usia 0-5 tahun yaitu $18-20$ gigi (35,5\%). Inilah yang menunjukkan bahwa semakin lama pemberian susu formula pada anak dapat menyebabkan tingkat keparahan karies.

Tabel. 5 Hubungan Antara Pemberian Susu Formula dengan Kejadian Karies

\begin{tabular}{|c|c|c|c|}
\hline \multirow{2}{*}{ Pemberian Susu Formula } & \multicolumn{2}{|c|}{ Kejadian Karies } & \multirow{2}{*}{ Total } \\
\cline { 2 - 3 } & Karies & Tidak Karies \\
\hline Minum Susu Formula : & $24(48,0 \%)$ & $8(16,0 \%)$ & $32(64,0 \%)$ \\
\hline Ya & $11(22,0 \% 0$ & $7(14 \%, 0)$ & $18(36,0 \%)$ \\
\hline Tidak & $\mathbf{3 5 ( 7 0 , 0 \% )}$ & $\mathbf{1 5 ( 3 0 , 0 \% )}$ & $\mathbf{5 0 ( 1 0 0 \% )}$ \\
\hline Total
\end{tabular}


Tabel 5 menunjukkan hubungan antara pemberian susu formula dengan kejadian karies. Responden yang menberikan susu formula pada anak dan terjadi karies adalah sebanyak 24 sampel (48.0\%). Sedangkan responden yang tidak memberikan susu formula dan tetap terjadi karies dini pada anak berjumlah 11 sampel $(22,0 \%)$. Adapun responden yang memberikan susu formula dan tidak terjadi karies dini pada anak berjumlah 8 sampel (16,0\%). Sedangkan responden yang tidak memberikan susu formula dan tidak terjadi karies sebanyak 7 sampel $(14,0 \%)$. Hal inilah yang menunjukkan bahwa sebagian besar sampel yang diberikan susu formula ternyata terjadi karies pada anak.

Tabel 6, Hubungan Antara Lama Pemberian Susu Formula dengan Tingkat Keparahan Karies

\begin{tabular}{|l|l|l|}
\hline \multicolumn{1}{|c|}{ Kriteria } & Karies & Tingkat Keparahan Karies \\
\hline Minum Susu & 0,032 & 0,016 \\
\hline Lama MInum Susu & 0,026 & 0,033 \\
\hline
\end{tabular}

*Uji Statistik Person’s Correlation test ; $<<0,05$

Tabel 6 dengan menggunakan uji statistik memperlihatkan hubungan lamanya pemberian susu formula dengan tingkat keparahan karies. Hal ini terlihat pula pada tabel 5 bahwa rata-rata lama pemberian susu formula sekitar 1 tahun 5 bulan hingga 1 tahun 6 bulan dapat menyebabkan karies hingga daerah pulpa dan sisa akar. Selain itu, jumlah gigi yang terdiagnosis karies pada enamel lebih tinggi dibandingkan pada daerah lain, yaitu lima hingga enam gigi. Paling sedikit diperoleh pada penelitian ini adalah karies yang mencapai daerah pulpa yaitu hanya dua gigi.

Melalui tabel 6 juga diperoleh hasil uji statistik korelasi pearson antara tingkat keparahan karies dengan lama pemberian susu formula. Sejalan dengan table 6 tersebut yang menunjukkan bahwa ada hubungan yang signifikan antara pemberian susu formula dengan tingkat kejadian karies. Pada tabel 6 ini juga diperoleh nilai $p$ value dibawah $0,05(p<0,05)$ untuk seluruh tingkat keparahan karies, yang artinya terdapat hubungan yang signifikan antara lama pemberian susu formula dengan tingkat keparahan karies. Dari hasil penelitian di atas, peneliti menyimpulkan bahwa semakin lama anak minum susu formula membuktikan bahwa semakin banyak sampel yang terkena karies. Demikian juga semakin lama minum susu formula yang ditemukan pada sampel maka tingkat keparahan karies giginya juga meningkat.

Menurut (Purnamasari, 2007), pemberian susu formula atau cairan manis di dalam botol terlalu lama menempel pada permukaan gigi serta makanan manis dan lengket lainnya dapat menyebabkan terjadinya karies pada anak. Selain itu, dengan berkembangnya tekhnologi, seiring dengan penggunaan susu formula yang sudah dipengaruhi oleh keadaan sosial ekonomi dan ibu-ibu dengan kesibukan bekerja.

Penelitian pada anak usia 4-6 tahun tentang lamanya pemberian susu formula dapat dilihat sebagai berikut. Rata-rata usia pada sampel penelitian ini adalah anak umur lima tahun. Sampel penelitian lebih banyak minum susu formula daripada minum air susu ibu (ASI), yaitu 32 orang (64\%) minum susu formula dan 18 orang (36\%) yang tidak mengkonsumsi susu formula. Adapun rata-rata lama pemberian susu formula adalah satu setengah tahun sampai dua tahun. 
Hampir seluruh responden memberikan ASI pada anaknya., namun hanya 32 responden (64\%) yang memberikan susu formula dari botol setelah pemberian ASI. Sifat fisik makanan yang mengandung karbohidrat memainkan peranan yang sangat penting dalam proses pembentukan karies. Semakin lama sesuatu makanan yang mengandung karbohidrat itu berkontak dengan permukaan email gigi, semakin besar pula kemungkinan untuk waktu lamanya produksi asam di rongga mulut. Akibatnya, tingkat demineralisasi asam dari email dapat langsung berhubungan dengan jumlah waktu makanan tersebut melekat pada permukaan gigi.

Frekuensi mengkonsumsi sukrosa yang tinggi meningkatkan keasaman plak dan meningkatkan potensi pembentukan plak serta pertumbuhan bakteri di rongga mulut. Plak paling aktif bekerja di malam hari, pada saat anak dalam keadaan istirahat. Makan selama tidur meningkatkan resiko karies gigi karena kebersihan mulut dan laju aliran saliva menurun saat tidur. Sehingga mengkonsumsi minuman/makanan yang mengandung gula dengan botol harus dikurangi atau dihentikan pada saat malam hari (tidur). Untuk mengurangi resiko karies gigi, salah satu metode yang harus dilakukan adalah memberikan pendidikan kesehatan kepada orang tua tentang cara pengelolaan susu formula serta perawatan gigi anak. Sehingga orang tua lebih dapat memahami cara pengelolaan pemberian susu formula pada anak agar terhindar dari karies gigi.

\section{KESIMPULAN}

Berdasarkan dari hasil penelitian Hubungan Lamanya Pemberian Susu Formula Dengan Tingkat Keparahan Karies Gigi pada Anak Usia 4-6 Tahun Di TK Pancamarga Kecamatan Tanete Riattang Kabupaten Bone pada tanggal 24 Januari 2020 dapat disimpulkan bahwa terdapat hubungan antara lama pemberian susu dengan tingkat keparahan karies pada anak usia 4-6 tahun di TK Pancamarga. Seperti sebelumnya telah diuraikan bahwa semakin lama mengkonsumsi susu formula, maka semakin tinggi tingkat keparahan karies gigi pada anak. Ini terbukti dari sampel yang telah diteliti. Terbukti bahwa terdapat hubungan antara kejadian karies dengan minum susu formula. Yaitu Semakin lama anak minum susu formula pada sampel ditemukan banyak terkena rampan karies. Minimnya pengetahuan orang tua untuk menjaga kesehatan gigi anak usia dini. Sebagai akibatnya kebanyakan orang tua memberikan makanan/minuman manis dalam waktu yang lama dan kurangnya mengkonsumsi makanan yang berserat, sayur-sayuran dan buah-buahan. Orang Tua (Responden) sangat antusias menjawab Kuesioner yang kami berikan, dan Murid TK Pancamarga Kecamatan Tanete Riattang Barat Kabupaten Bone juga sangat senang dan tenang untuk diperiksa giginya.

\section{SARAN}

Diharapkan bagi peneliti selanjutnya yang ingin meneliti lebih jauh tentang hubungan lamanya pemberian susu formula dengan tingkat keparahan karies gigi pada anak, penelitian ini bisa dijadikan dasar dengan menggunakan sampel yang lebih besar serta menerapkan metode lain yang lebih efektif. Selain itu, diharapkan pula untuk memperhatikan bagaimana pola konsumsi susu formula yang baik, seperti tidak membiarkan mengkonsumsi susu formula dengan frekuensi yang berlebihan dan tidak membiasakan anak tertidur dalam keadaan mengisap dot.

\section{DAFTAR PUSTAKA}

Achmad, Harun, Karies dan Perawatan Pulpa pada Gigi Anak. 2015. Jakarta : Penerbit Sentasi Putra.

Budiyanti, EA, Perawatan Endodontik pada Anak. 2014. Jakarta : Penerbit Buku EGC.

Jingga, Erliana, dkk, Hubungan Pola Pemberian Susu Formula dengan Kejadian Early Childhood Caries (ECC) pada Anak Prasekolah, Jurnal kesehatan 
Masyarakat, 2019.

Kidd, Edwina A,M, dkk, Dasar-Dasar Karies Penyakit dan Penanggulangannya, 1991. Jakarta : EGC.

Mariati, Ni Wayan, Pencegahan dan Perawatan Karies Rampan. Jurnal Kedokteran Gigi, 2015. Nirwana, AB, Asi dan Susu Formula. 2014. Yogyakarta : Penerbit Nuha Medika.

Scheid, Rickne C. Weiss Gabriela, Anatomi Gigi. Edisi 8. EGC;2002.

Srigupta, AA, PanduanSingkat Perawatan Gigi dan Mulut. 2004. Jakarta : Penerbit Hasan Medika.

Suparlan, L.L, dkk, Hubungan Peran Orang Tua dalam Pengelolaan Pemberian Susu Formula Botol dengan Kejadian Karies Gigi pada Balita, Jurnal Kedokteran Gigi, 2018.

Susanto, Hery, dkk, Faktor-Faktor yang Mempengaruhi Pemberian Susu Formula pada Bayi. Jurnal e-Clinic, Volume 3, Nomor 1, 2015.

Tarigan, Rasinta, Karies Gigi Edisi 4.2014. Jakarta : Penerbit Buku EGC.

Widyastuti, Erlina, Motivasi Wanita Bekerja dalam Memberikan Susu Formula pada Bayi Usia 0-6 Bulan. Jurnal Kedokteran Gigi, 2011.

Zahara, Elfi dan Andriani, Hubungan Pemberian Susu Menggunakan Botol dengan Rampan Karies pada Murid, Jurnal Averrous, Volume 4, Nomor 1, 2018. 